\title{
Colorectal Cancer pT3 TNM Finding v6
}

National Cancer Institute

\section{Source}

National Cancer Institute. Colorectal Cancer pT3 TNM Finding v6. NCI Thesaurus. Code C60846.

Colorectal cancer with invasion through the muscularis propria into the submucosa, or into non-peritonealized pericolic or perirectal soft tissues. (from AJCC 6th Ed.) 